\title{
PI4KB wt Allele
}

National Cancer Institute

\section{Source}

National Cancer Institute. PIAKB wt Allele. NCI Thesaurus. Code C51168.

Human PI4KB wild-type allele is located within $1 \mathrm{q} 21$ and is approximately $36 \mathrm{~kb}$ in length.

This allele, which encodes phosphatidylinositol 4-kinase beta protein, plays a role in the phosphorylation of phosphatidylinositol to initiate production of the second messenger inositol-1,4,5,-trisphosphate. 